\title{
EFFECT OF HEATED ONION EXTRACT ON WHITE BUTTON MUSHROOM (AGARICUS BISPORUS) POLYPHENOL OXIDASE
}

\author{
Chen Wai Wong ${ }^{1 凶}$, Amelia Yen Fang Toh ${ }^{1,2}$ and Win Yee Lim ${ }^{1}$ \\ ${ }^{1}$ Department of Biotechnology, Faculty of Applied Sciences, UCSI University, No. 1, Jalan Menara Gading, \\ UCSI Heights, 56000 Kuala Lumpur, Malaysia. \\ ${ }^{2}$ Novozymes Malaysia Sdn Bhd, Jalan Inovasi 1, Technology Park Malaysia, 57000 Bukit Jalil, Kuala Lumpur, \\ Malaysia. \\ $\otimes_{\text {wongcw@ucsiuniversity.edu.my }}$ \\ https://doi.org/10.34302/crpjfst/2021.13.4.2 \\ Article history: \\ Received: \\ 18 January 2021 \\ Accepted: \\ 18 October 2021 \\ Keywords: \\ Polyphenol oxidase, \\ Agaricus bisporus, \\ Onion extract, \\ Inhibitor.

\section{ABSTRACT} \\ Heated onion extract exhibited a more potent inhibitory effect towards the \\ browning of button mushroom (Agaricus bisporus) compared with the fresh \\ onion. The inhibitions were $65.10 \%$ and $25.33 \%$ for fresh onion extracts for \\ pyrocatechol and 4-methylcatechol, respectively. The percentage of \\ inhibition increased to $68.51 \%$ for pyrocatechol and $42.33 \%$ for 4 - \\ methylcatechol when added with the heated onion extracts. Onion extracts \\ inhibited the white button mushroom PPO non-competitively. The \\ inhibitory efficiency of the onion extracts increased with increasing heating \\ temperature and time. The percentage of inhibition for the non-heated onion \\ extracts declined drastically from $89 \%$ to $50 \%$ for pyrocatechol and $77 \%$ to \\ $31 \%$ for 4 -methylcatechol after 9 days of storage at $4{ }^{\circ} \mathrm{C}$. Meanwhile, \\ percentage of inhibition declined from $93 \%$ to $64 \%$ and $83 \%$ to $36 \%$ for \\ pyrocatechol and 4-methylcatechol for heated onion extracts. Onion extract \\ could be considered as a potential natural inhibitor for preventing browning \\ of fruits and vegetables.
}

\section{Introduction}

Browning usually occurs in vegetables and fruits during handling, processing and storage. Food browning is normally undesirable due to a reduction in nutritional value, change in sensory perceptions, and decreased consumer acceptance of food (Lim et al. 2020). The enzyme that is responsible for the enzymatic browning of fruits and vegetables is known as polyphenol oxidase (PPO). PPO (EC 1.14.18.1) catalyzes hydroxylation of monophenols to $O$ diphenols, followed by oxidation of $o$-diphenols to $o$-quinones in the presence of oxygen, which lead to the formation of brown pigments (ErciliCura et al. 2015).

White button mushrooms (Agaricus bisporus), also known as champignon mushrooms and common mushrooms, which belongs to family Agaricaceae (Rachappa et al.
2020). It is one of the most popular edible fungi in the world. White button mushrooms are a good source of protein, minerals and vitamins such as vitamin $\mathrm{C}, \mathrm{B}$ complexes and $\mathrm{D}$. Besides the nutritional value, these edible mushrooms are also famous for their medicinal properties (Rachappa et al. 2020; Sinha et al. 2021). However, white button mushrooms have very short shelf life of between 3 to 5 days which is mainly due to the post-harvest enzymatic browning (Gholami et al. 2017). Therefore, it is important to study and control enzymatic browning of mushrooms in order to extend their commercial shelf life while preserving their nutritional value.

Chemicals anti-browning agents such as Lcysteine, sodium metabisulfite, have been the most studied for the used in processed foods. However, consumers are concern about sulphite 
containing browning agents could cause problem to human health. Thus, this present research was to look for alternative ways to prevent and delay enzymatic browning of white button mushrooms. Onion was used as a natural inhibitor to investigate its inhibition towards white button mushroom PPO.

\section{Materials and methods}

\subsection{Plant materials and chemicals}

Fresh white button mushrooms (Agaricus bisporus) were bought from a local market in Kuala Lumpur. They were supplied by Champ Fungi Sdn. Bhd. in Telok Gong, Port Klang, Selangor, Malaysia. Red onions were bought from local market (Giant Hypermarket, Taman Connaught, Cheras, Kuala Lumpur). All chemicals used were analytical grade and were used as obtained.

\subsection{Enzyme extraction}

The extraction method was adopted from Wong and Lee (2014) with slight modification. White button mushrooms $(60 \mathrm{~g})$ were washed and sliced. The samples were then homogenized with $600 \mathrm{~mL}$ of $0.05 \mathrm{M}$ sodium phosphate buffer $\left(4^{\circ} \mathrm{C}, \quad \mathrm{pH} 6.8\right)$ and $1 \% \quad(\mathrm{w} / \mathrm{v})$ of polyvinylpyrrolidone using an LB-8011ES industrial blender (Waring Laboratory, Torrington, CA, USA) at maximum speed $(22,000 \mathrm{rpm})$ for 3 minutes. The homogenates were then subjected to centrifugation at 8000 rpm for 15 min at $4^{\circ} \mathrm{C}$ using a Universal 320R centrifuge (Hettich, Tuttlingen, Germany). The supernatant containing PPO was filtered under vacuum by Buchner filter (WP6211560 Vacuum pressure pump, Millipore Sigma, Burlington, MA, USA). The filtrate obtained was pipetted drop by drop into $600 \mathrm{~mL}$ of cold acetone ($\left.20^{\circ} \mathrm{C}\right)$. The precipitates obtained were centrifuged at $8000 \mathrm{rpm}$ for $15 \mathrm{~min}$ at $4^{\circ} \mathrm{C}$. The white resultant powder was dried overnight at room temperature and stored at $4^{\circ} \mathrm{C}$. In order to obtain the enzyme extracts, $1 \mathrm{~g}$ of acetone powder was suspended in $10 \mathrm{~mL}$ of pre-chilled $0.05 \mathrm{M}$ sodium phosphate buffer $(\mathrm{pH} \mathrm{6.8)}$ and stirred until all the powders were dissolved. The suspension was then centrifuged at $8000 \mathrm{rpm}$ for
$15 \mathrm{~min}$ at $4^{\circ} \mathrm{C}$. The supernatant was used as the crude PPO extract.

\subsection{Onion extract preparation}

Red onions were used as natural inhibitors and the preparation of red onions was slightly modified from Lim et al. (2019). Red onions $(100 \mathrm{~g})$ were rinsed and sliced into small pieces. All the pieces of red onions were then homogenized with $100 \mathrm{~mL}$ of $0.05 \mathrm{M}$ sodium phosphate buffer ( $\mathrm{pH} \mathrm{6.8)}$ at 22, $000 \mathrm{rpm}$ for 3 min. Homogenized onion was centrifuged at $8000 \mathrm{rpm}$ for $15 \mathrm{~min}$. After centrifugation, the supernatant was then filtered and the filtrate was used as the fresh onion extract. Heated onion extract was prepared by incubating the fresh onion extract at $100^{\circ} \mathrm{C}$ for 10 minutes.

\subsection{Influence of heat treatment temperature for onion extract on the inhibitory effect of white button mushroom PPO}

Onion extracts were immersed in a water bath (Memmert Lab Companion, Jeio Tech, Selangor, Malaysia) in a temperature range of $30-100^{\circ} \mathrm{C}$ for $10 \mathrm{~min}$ prior to the PPO assay.

\subsection{Influence of heat treatment time for onion extract on the inhibitory effect of white button mushroom PPO}

This assay was done by preparing the heated onion extracts by immersing the onion extract into a water bath (Memmert Lab Companion, Jeio Tech, Selangor, Malaysia) at $100^{\circ} \mathrm{C}$. An aliquot of onion extract was removed from the water bath at every 2 min interval until $14^{\text {th }}$ min. The onion extract was then immediately cooled down to room temperature prior to the addition into the reaction mixture for PPO assay.

\subsection{Influence of storage time of fresh and heated onion extracts on the inhibitory effect of white button mushroom PPO}

Fresh onion and heated onion extracts prepared were kept in the refrigerator for 9 days. Aliquots of the onion extracts were taken on day $1,3,5,7,9$ to be added into the reaction mixture. The efficacy of the inhibition was determined by measuring the absorbance by using a 
spectrophotometer (Secoman, Champigny-surMarne, France).

\subsection{Assay of PPO activity}

PPO activity was determined via measurement of an increase in absorbance at 400 $\mathrm{nm}$ for pyrocatechol and $410 \mathrm{~nm}$ for 4methylcatechol, respectively by using a PRIM Light spectrophotometer (Secoman, Champigny-sur-Marne, France) at 15 seconds interval. The reaction mixture contained $0.1 \mathrm{~mL}$ of enzyme solution, $0.9 \mathrm{~mL}$ of $0.05 \mathrm{M}$ sodium phosphate buffer ( $\mathrm{pH} 6.8), 1 \mathrm{~mL}$ of onion extract $(1 \mathrm{~g} / \mathrm{mL})$ as inhibitor and $1 \mathrm{~mL}$ of substrate. A control contained of $0.1 \mathrm{~mL}$ of enzyme solution, $1.9 \mathrm{~mL}$ of $0.05 \mathrm{M}$ sodium phosphate buffer $(\mathrm{pH}$ 6.8 ) and $1 \mathrm{~mL}$ of substrate. The initial velocity was calculated from the slope of the absorbance $v s$. time curve, where a single unit of PPO activity was defined as the amount of enzyme that caused a 0.001 absorbance change per min (Lim et al. 2019).

\subsection{Statistical analysis}

All the experimental data was performed by using Microsoft Office Excel. The data were presented as mean \pm standard deviation (SD) $(\mathrm{n}=3)$ and also as percent relative activity.

\section{Results and discussions}

\subsection{Inhibitory effect of onion extract on white} button mushroom PPO

Table 1 shows the inhibitory effect of onion extract on white button mushroom PPO activity. Regardless of the substrate used, the heated onion extract at $100^{\circ} \mathrm{C}$ for 10 min exhibited a stronger inhibitory effect on white button mushroom PPO than did the fresh onion extract. These results were in agreement with those reported by Lim et al. (2019), Lim and Wong (2018), Wong and Lee (2014) and Kim et al. (2005) when sweet potato PPO, ginger PPO, cassava leaves PPO and pear PPO, were treated with heated onion extracts respectively.

However, a higher inhibition percentage of white button mushroom PPO by heated onion extract was found from this study $(68.51 \%)$ than that of sweet potato (41.47\%) (Lim et al. 2019) as well as ginger (33.11\%) as reported by Lim and Wong (2018). Maillard reaction products produced during heating of onion extract probably would increase the inhibitory effect on browning of white button mushroom (Kim et al. 2005). It was also reported that the thiol compounds contained in onion might be the active components responsible for the inhibition of browning (Phisut and Jiraporn 2013; Akhtar 2015).

Table 1. The effect of natural inhibitors on white button mushroom PPO

\begin{tabular}{|c|c|c|c|c|c|}
\hline Substrate & Inhibitor & Inhibition (\%) & $\begin{array}{c}\mathrm{K}_{\mathrm{m}} \\
(\mathrm{mM})\end{array}$ & $\begin{array}{c}\mathrm{V}_{\max } \\
(\mathrm{EU} / \mathrm{min} / \mathrm{ml})\end{array}$ & $\begin{array}{c}\text { Type of } \\
\text { inhibition }\end{array}$ \\
\hline Pyrocatechol & $\begin{array}{c}\text { Fresh } \\
\text { onion extract }\end{array}$ & $64.74 \pm 3.76$ & 21.22 & 1414.43 & $\begin{array}{c}\text { Non- } \\
\text { competitive }\end{array}$ \\
\cline { 2 - 6 } & $\begin{array}{c}\text { Heated } \\
\text { onion extract }\end{array}$ & $68.51 \pm 2.19$ & 21.93 & 1096.49 & $\begin{array}{c}\text { Non- } \\
\text { competitive }\end{array}$ \\
\cline { 2 - 6 } & Control & - & 21.05 & 3508.77 & - \\
\hline \multirow{3}{*}{$\begin{array}{c}4- \\
\text { methylcatechol }\end{array}$} & $\begin{array}{c}\text { Fresh } \\
\text { onion extract }\end{array}$ & $25.33 \pm 0.65$ & 24.92 & 778.82 & $\begin{array}{c}\text { Non- } \\
\text { competitive }\end{array}$ \\
\cline { 2 - 6 } & $\begin{array}{c}\text { Heated } \\
\text { onion extract }\end{array}$ & $42.33 \pm 1.77$ & 25.58 & 639.39 & $\begin{array}{c}\text { Non- } \\
\text { competitive }\end{array}$ \\
\cline { 2 - 6 } & Control & - & 25.25 & 1010.10 & - \\
\hline
\end{tabular}




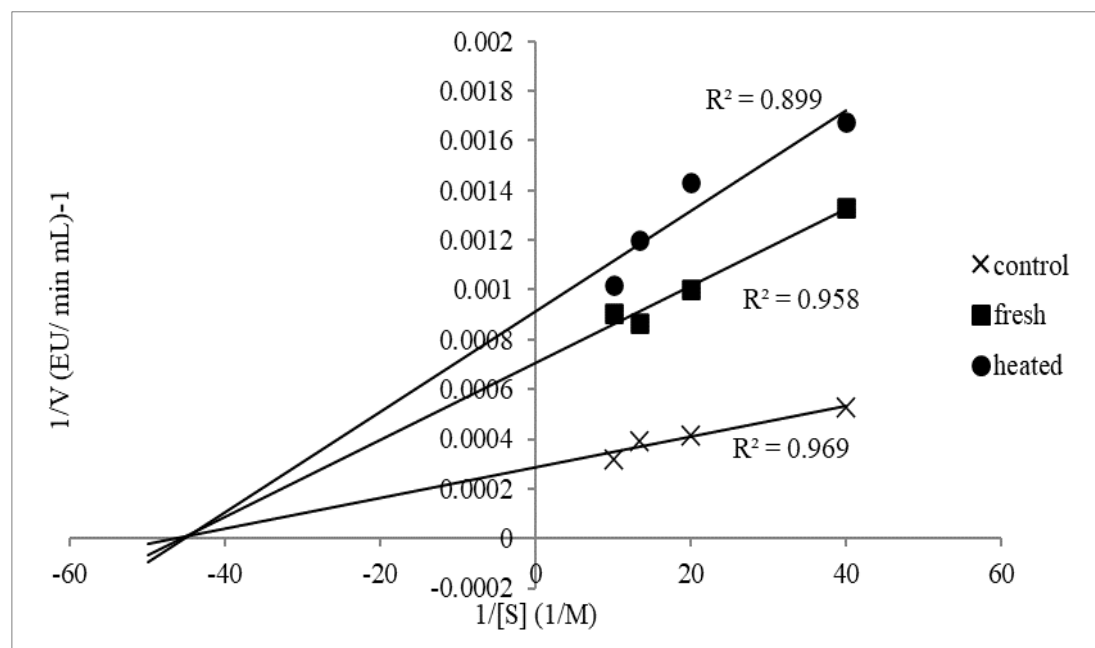

Figure 1. Lineweaver-Burk plot of fresh onion extract and heated onion extract on white button mushroom PPO using pyrocatechol.

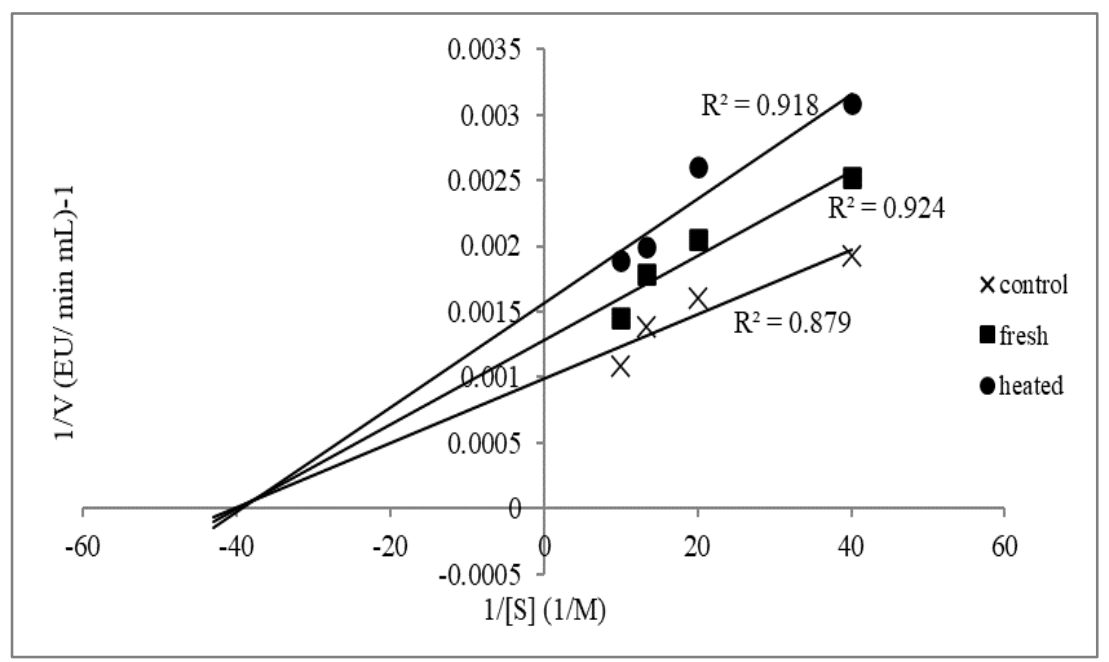

Figure 2. Lineweaver-Burk plot of fresh onion extract and heated onion extract on white button mushroom PPO using 4-methylcatechol.

Figures 1 and 2 show the Lineweaver-Burk plots of white button mushroom PPO in the presence of fresh onion extract and heated onion extract using pyrocatechol (Figure 1) and 4methylcatechol (Figure 2), respectively. It can be seen that both the fresh and heated onion extracts inhibited the white button mushroom PPO non-competitively as the $\mathrm{K}_{\mathrm{m}}$ of the enzyme was similar; while the $V_{\max }$ values decreases with the addition of both fresh and heated onion extracts. Similar type of inhibition has been found by Wong and Lee (2014) for cassava leaves PPO, which was non-competitive. According to Mohan et al. (2013), a noncompetitive inhibitor binds to the enzyme other than active site and does not affect the affinity of the enzyme for the substrate. However, different type of inhibitions were found when onions were used to inhibit yam and ginger PPO (Yapi et al. 2015; Lim and Wong 2018).

The $\mathrm{V}_{\max }$ values dropped drastically from an initial of $3508.77 \mathrm{EU} / \mathrm{min} \mathrm{ml}$ to $1414.43 \mathrm{EU} / \mathrm{min}$ $\mathrm{mL}$ and 1096.49 EU/min $\mathrm{mL}$, respectively when fresh and heated onion extracts were added with pyrocatechol as the substrate. The $\mathrm{V}_{\max }$ decreased to $778.82 \mathrm{EU} / \mathrm{min} \mathrm{ml}$ and 639.39 $\mathrm{EU} / \mathrm{min} \mathrm{ml}$ respectively from $1010.10 \mathrm{EU} / \mathrm{min}$ $\mathrm{ml}$ for 4-methylcatechol, when fresh and heated onion extracts were added (Table 1). 35\% and $31 \%$ of the PPO activities retained when the 
fresh and heated onion extracts for pyrocatechol and $75 \%$ and $58 \%$ of the PPO activities retained when the fresh and heated onion extracts for 4methylcatechol (Table 1). These results show that onion extracts posed a higher inhibition power when pyrocatechol was used as substrate as higher percentages of PPO activities were inhibited.

\subsection{Influence of heat treatment temperature for onion extract on the inhibitory effect of white button mushroom PPO}

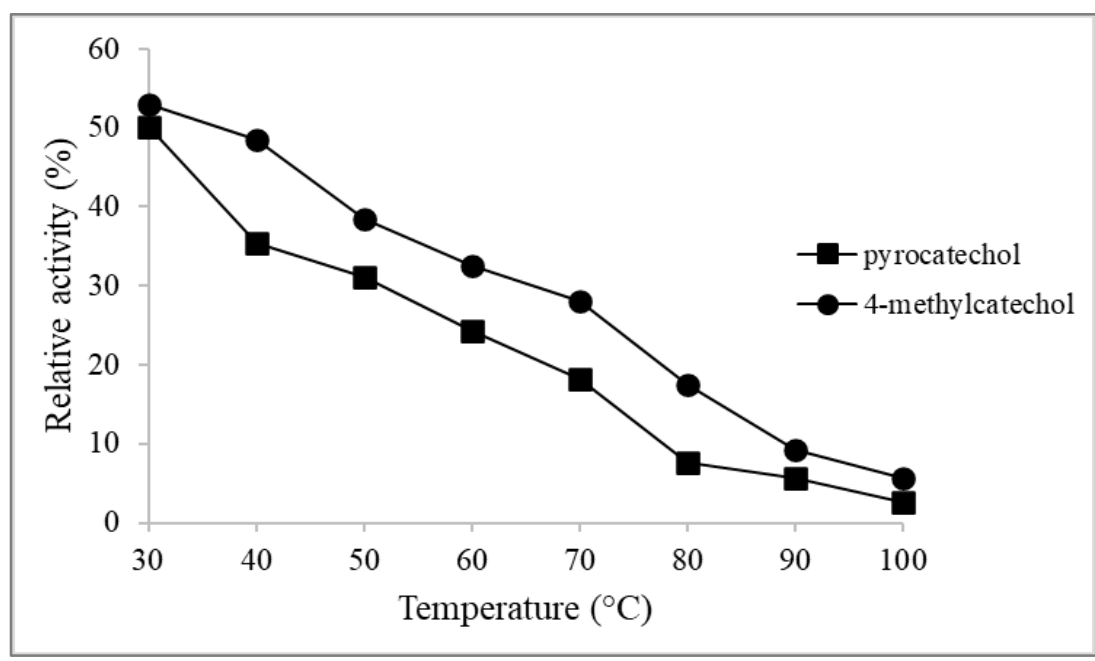

Figure 3. Effect of heating temperature of onion extract on the inhibitory effect of white button mushroom PPO

Figure 3 exhibits the inhibitory effect of onion extract after heating at various temperatures $\left(30-100^{\circ} \mathrm{C}\right)$ for $10 \mathrm{~min}$ using pyrocatechol and 4-methylcatechol, respectively. As shown in Figure 3, onion extracts treated at a higher temperature exhibited a stronger inhibition towards white button mushroom PPO. This phenomenon was probably due to the inhibitory effect of Maillard reaction products increased with increasing treatment temperature (Lim et al. 2019).

The percentage of inhibition for the heated onion extracts increased from $47 \%$ to $94 \%$ and $50 \%$ to $97 \%$ with the increased of incubation temperatures from 30 to $100^{\circ} \mathrm{C}$ using 4methylcatechol and pyrocatechol, respectively in this study. Similar results were obtained by Lee (2007) whereby the banana PPO activity markedly inhibited $(22 \%$ to $65 \%)$ when the onion extracts were added after heating from 50 to $100^{\circ} \mathrm{C}$.

\subsection{Influence of heat treatment time for onion extract on the inhibitory effect of white button mushroom PPO}

As shown in Figure 4, the longer the heating time on the onion extracts, the higher the decrease in residual PPO activity. Only 3\% and $12 \%$ of relative PPO activities were found for 4 methylcatechol and pyrocatechol, respectively after 14 minutes heating of the onion extracts. These could be caused by the prolonged heating times may produce an increasing amount of inhibitory compounds, already formed at shorter heating times and or generate additional inhibitory compounds. The findings from this study was in agreement with those reported by Lee et al. (2007), whereby inhibition of taro PPO was increased with increasing of heating time for onion extracts. 


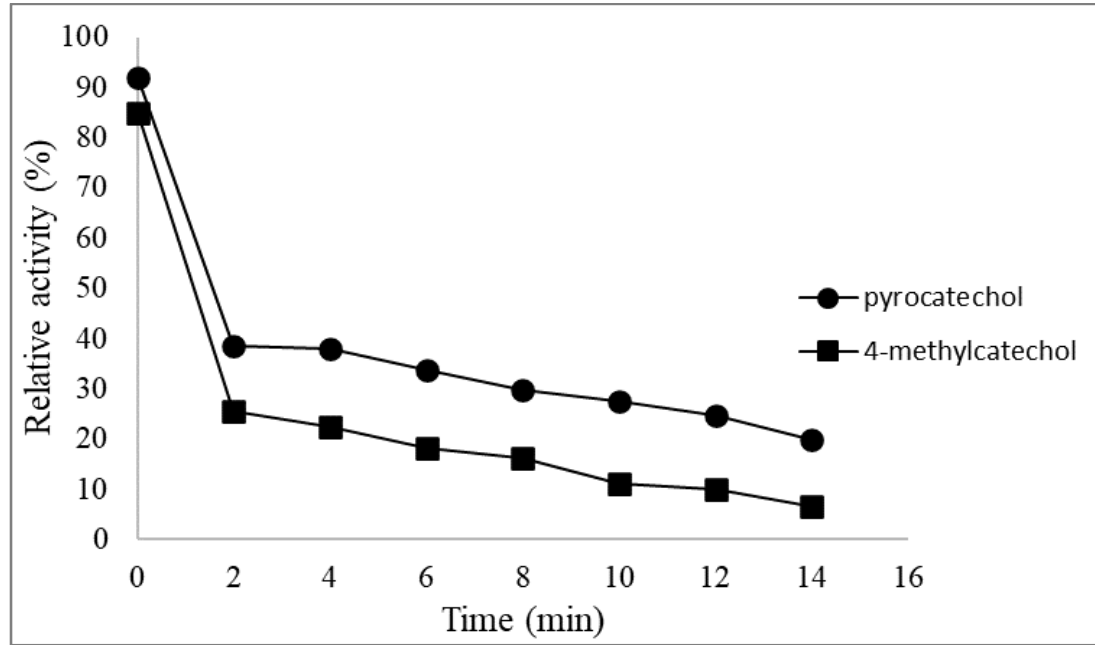

Figure 4. Effect of heating time of onion extract on the inhibitory effect of white button mushroom PPO

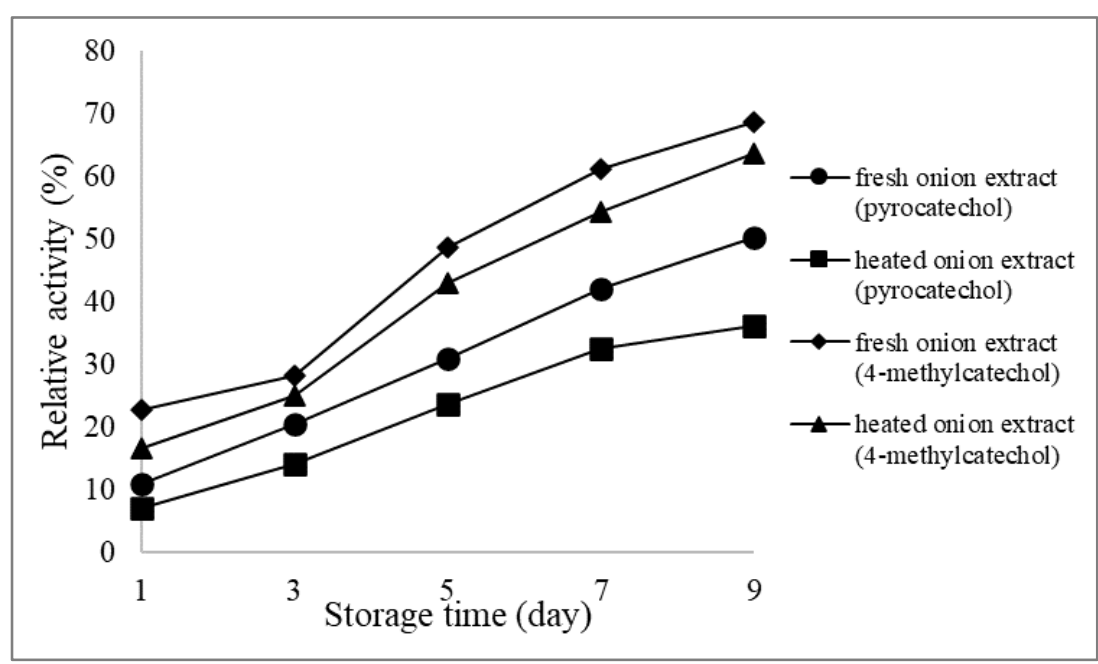

Figure 5. Effect of storage time of fresh and heated onion extracts on the inhibitory effect of white button mushroom PPO

\subsection{Influence of storage time of fresh and heated onion extracts on the inhibitory effect of white button mushroom PPO}

According to Figure 5, the relative PPO activities increased with the increasing of storage time, which indicated that the inhibitory effect of the onion extracts decreased with increased of storage time. It was noted that the relative PPO activity of white button mushroom increased from $11 \%$ to $50 \%$ in the presence of non-heated onion extracts, whereas $36 \%$ of the PPO activity was retained at day 9 of storage for the heated onion extracts when pyrocatechol was used. The fresh onion extracts showed nearly $77 \%$ inhibition when 4-methylcatechol was employed in the reaction mixture. However, the inhibitory effect drastically dropped to $31 \%$ after 9 days of storage. Similar pattern were observed when heated onion extracts were used, whereby a lower relative activity was obtained with 4-methylcatechol. The explanation for this could be due to the decreased in antioxidant activity of onion extracts with the increased of storage time (Lanzotti 2006).

\section{Conclusions}

This concluded that onion extract can be used as a natural inhibitor to prevent browning of white button mushroom. It can be potentially used to replace sulphite-containing anti- 
browning agents and other chemical inhibitors which would possibly cause undesirable side effects. Inhibitory effect markedly increased with increase in temperature for a definite time and with heating time at a fixed temperature, while inhibitory effect decreased with storage time.

\section{References}

Akhtar, S. (2015). Advances in conventional breeding approaches for postharvest quality improvement in vegetables. In M.W. Siddiqui (Ed.), Postharvest biology and technology of horticultural crops: principles and practices for quality maintenance. (pp. 141-192), Boca Raton: CRC Press.

Ercili-Cura, D., Huppertz, T. and Kelly, A. L. (2015). Enzymatic modification of dairy product texture. In J. S. Chen and R. Andrew (Eds.), Modifying food texture: Novel ingredients and processing techniques (pp. 71-97). London: Woodhead Publishing.

Gholami, R., Ahmadi, E., and Farris, S. (2017). Shelf life extension of white mushrooms (Agaricus bisporus) by low temperatures conditioning, modified atmosphere, and nanocomposite packaging material. Food Packaging and Shelf Life, 14, 88-95.

Kim, M.J., Kim, C.Y., and Park, I. (2005). Prevention of enzymatic browning of pear by onion extract. Food Chemistry, 89(2), 181-184.

Lanzotti, V. (2006). The analysis of onion and garlic. Journal of Chromatography $A$, 1112(1-2), 3-22.

Lee, M.K. (2007). Inhibitory effect of banana polyphenol oxidase during ripening of banana by onion extract and Maillard reaction products. Food Chemistry, 102, 146-149.

Lee, M.Y., Lee, M.K. and Park, I. (2007). Inhibitory effect of onion extract on polyphenol oxidase and enzymatic browning of Taro (Colocasia antiquorum var. esculenta). Food Chemistry, 105, 528532.
Lim, W.Y. and Wong, C.W. (2018). Inhibitory effect of chemical and natural anti-browning agents on polyphenol oxidase from ginger (Zingiber officinale Roscoe). Journal of Food Science Technology, 55(8), 30013007.

Lim, W.Y., Cheng, Y.W., Lian, L.B., Chan, E.W.C. and Wong, C.W. (2021). Inhibitory effect of Malaysian coastal plants on banana (Musa acuminata colla "Lakatan"), ginger (Zingiber officinale Roscoe) and sweet potato (Ipomoea batatas) polyphenol oxidase. Journal of Food Science and Technology, 58(11), 4178-4184.

Lim, W.Y., Cheun, C.F. and Wong, C.W. (2019). Inhibition of enzymatic browning in sweet potato (Ipomoea batatas (L)) with chemical and natural anti-browning agents. Journal of Food Processing and Preservation, 43(11), e14195.

Mohan, C., Long, K. D. and Mutneja, M. (2013). An introduction to inhibitors and their biological applications. (1st ed.). Billerica, MA: EMD Millipore Corporation.

Phisut, N. and Jiraporn, B. (2013). Characteristics and antioxidant activity of Mailard reaction products derived from chitosan-sugar solution. International Food Research Journal, 20, 1077-1085.

Rachappa, P., Sudharma, D.C., Chauhan, O.P., Patki, P.E., Nagara, R. and Naik, S.N.R. (2020). Development and evaluation of white button mushroom based snacks. Journal of Food Processing and Technology, 11(3), 824.

Sinha, S.K., Upadhyay, T.K. and Sharma, S.K. (2021). Nutritional-medicinal profile and quality categorization of fresh white button mushroom. Biointerface Research in Applied Chemistry, 11(2), 8669-8685.

Wong, C.W. and Lee, P.L.A. (2014). Inhibitory effect of onion extract on cassava leaf (Manihot esculenta Crantz) polyphenol oxidase. International Food Research Journal, 21(2), 755-758.

Yapi, J.C., Gnangui, S.N. and Dabonné, S. (2015). Inhibitory effect of onions and garlic extract on the enzymatic browning of an 
edible yam (Dioscorea cayenensisrotundata cv. Kponan) cultivated in Côte d Ivoire. International Journal of Current Research and Academic Review, 3(1), 219231. 